\title{
Empirical Analysis of Determinants of Profitability of Banks: Evidence from Indian Public Sector Banks
}

\author{
Dr. Pritpal Singh Bhullar (Corresponding author) \\ Assistant Professor, Department of Humanities \& Management Studies \\ Giani Zail Singh Campus College of Eng. \& Technology \\ Maharaja Ranjit Singh Punjab Technical University, Bathinda (Punjab), India \\ E-mail: bhullar_pritpal36@yahoo.co.in
}

\section{Dr. Pradeep K. Gupta}

Assistant Professor, LM Thapar School of Management

Thapar Institute of Engineering \& Technology, (Deeemed-to-be-University), Patiala

Derabassi Campus, Derabassi-140507, Mohali (Punjab), India

E-mail: pradeep.gupta@thapar.edu

Received: November 29, 2017 Accepted: December 6, 2017 Published: December 25, 2017

doi:10.5296/ijafr.v7i2.12211

URL: https://doi.org/10.5296/ijafr.v7i2.12211

\begin{abstract}
The aim of present study is to empirically examine the impact of bank-specific determinants on the profitability of Indian public sector banks. A balanced panel data set comprising 280 observations of 28 Indian public sector banks over the period of ten years from 2006-07 to 2015-16 is used. The relevant financial data are collected from the Capitaline database. Net profit to Total funds is used as proxy for profitability of banks. A fixed effect regression model is built by devising statistical software STATA. The empirical results demonstrate non-uniform effects of selected financial characteristics on banks' profitability. The results also reveal that deposit ratios are the significant determinants of banks' profitability while Other Income to Total Income and Interest Income to Total Funds results a significant negative influence on bank performance. The results provide valuable insights to the banks that may assist in sustaining the financial stability in banking sector.
\end{abstract}

Keywords: Public sector banks, Profitability, Determinants, Panel data analysis, STATA 


\section{Introduction}

Sound banking system provides a firm ground for sustainable financial development in the country. Haque and Sharma (2011) emphasized upon the importance of efficient banking system in the sustainable economic growth which can be assessed by evaluating the financial performance of its banks. The attention on the benefits and risks for financial stability related with the changes in the financial market and the banking system was focused by Rena (2009) for the development of Indian economy. The significant inflows of foreign direct investment can certainly be attracted with the development of banking sector (Maswana, 2010). The banking system plays a role of indispensible actor in providing financial intermediation via converting the deposits into profitable investment that further enhances the revenue and brings the financial stability to the economy. Over the past one decade following the global financial meltdown, global banking system has encountered significant structural and regulatory challenges. The financial crisis in 2008 created sluggishness in the world trade and turbulence in financial markets resulting in low capital flows in the emerging markets. Succeeding the global financial crisis, numerous unfolding new challenges lead to reframe the organizational structure in banking sector across the globe. Altunbas et al. (2001) revealed that recent developments in financial sector regulations, technological and financial innovations are posing new challenges for financial institutions and banks in developing economies. Meghwal (2016) analyzed that Indian banking industry has been revolutionized enormously in last one decade due to transition from 'conventional banking' to 'digital banking'. All these multi-dimensional developments may have significant effect on the cost and revenue matrix that further influence the profitability of banking sector to a considerable extent from different aspects. The profitable banking sector is considered as major economic contributor to the development of country. The increasing significance of banking sector profitability in the economy and in enhancing shareholder's value leads to gain the prominent attention of many scholars. Many scholars have conducted their research for exploring the profitability determinants on the basis of conventional financial ratio. There have been wide literature on examining the profitability determinants in banks in developing and developed economies before the global recession but very few studies exhibit the investigation of profitability determinants in Indian Public sector in later part of global financial crisis. It has become important to empirically explore the profitability of banks with rapidly advancing economic and business scenario. Thus, the objective of the present study is to identify the bank-specific determinants which have an impact on the profitability of Indian public sector banks over the period of ten years from 2006-07 to 2015-16.

\section{Indian Banking Sector}

More than 70 per cent of assets of the banking sector in India are controlled by the public sector banks and a comparatively smaller share is left for private sector banks ${ }^{1}$. Thus, the determinants which have an impact on the profitability of banks are important to explore in case of Indian public sector banks. However, several private banks in India were licensed in the mid-1990s for increasing competition, enhancing efficiency, and inducing innovation in the Indian banking sector ${ }^{2}$ (Mohan and Ray, 2017). The banking sector in India is adequately capitalized and well-regulated as per the Reserve Bank of India (RBI). Owing to RBI's 
regulations, the Indian baking sector survived the aftermath of global financial crisis 2008 with no case of bankruptcy and this crisis led to regenerate the research thoughts on the profitability and capital adequacy ratio of banking sector (Pant and Nidugala, 2017). To develop a sound, competitive, inclusive, and customer-friendly banking sector, the RBI has introduced several innovative banking models like payment and small finance banks ${ }^{2}$ and the RBI will continue to supervise the regulatory reforms in the Indian banking industry like 'Payment and Settlement systems in India - Vision 2018' to step up the process of payment infrastructure for addressing the five C's of coverage, convenience, confidence, convergence, and $\operatorname{cost}^{3}$. The Indian public sector banks have been mobilizing resources from the distant rural areas and extending banking services to the remotest parts of the country since the 1970s and these public sector banks have also taken the burden of social agenda (Singh, 2016). Therefore, the measurement of the profitability of these banks to study is always an interest area for the various stakeholders of the public sector banks.

The rest of the paper is organized as follows: Section 2 reviews the existing scholarly studies on determinants of profitability of banks while Section 3 outlines the research methodology approach adopted and nature of sample data of financial determinants of banks. Section 4 presents the findings and discussion on the empirical results obtained from empirical models and the conclusions are drawn in Section 5. Implications of this study and suggestions for future research are discussed in Section 6.

\section{Review of Literature}

Numerous studies have examined the influence of financial variables on the profitability of banks. Generally positive impact has been found but no unanimous conclusion has been identified. The majority of studies have analyzed the conventional variables. Samad (2015) used the credit-deposit ratio for measuring liquidity characteristics of the banks in India. Return on Assets (hereafter, ROA) was used as a measure of the banks' profitability and a significant impact of the loan-deposit ratio on ROA has been found in his study. The credit-deposit ratio, introduced by Reserve Bank of India (RBI), is used as a measure of capacity of the banks to lend from their available resources for generating the revenues and improving the market share and it is also referred as loan-deposit ratio. Govil and Tripathi (2014) studied the various ratios for measuring the asset quality, profitability and liquidity positions of the top ten banks in India. As studied by Govil and Tripathi (2014), we also take credit to deposit, investment to deposit, and cash to deposit ratios for measuring the liquidity positions of public sector banks in India. Besides, profit before provisions to total funds, interest expended to interest earned, interest income to total funds, and other income to total income have also been included based on the study of Govil and Tripathi (2014).

Elisha and Guido (2016) investigate the profitability and bank specific variable sin 35 European banks over the period 2009- 2013. The results find that deposits and loans ratio has positive impact on the profitability of banks. Sharifi and Akhter (2016) studied the impact of the credit-deposit ratio on the profitability of the public sector banks in India. ROA, Return on Equity (hereafter, ROE), and Net Interest Margin (hereafter, NIM) were taken as the measures of the profitability of banks in India. They found that there is no significant impact 
of the credit-deposit ratio on Return on Assets and Return on Equity. Alalaya and Al Khattab (2015) empirically investigated the determinants affecting the profitability of banks and found a negative influence of ROA and GDP on profitability whereas positive influence of ROE and TD/TA on profitability of commercial banks has been noticed. Capraru and Ihnatov (2015) examined the negative impact of bank size, credit risk, market concentration and cost to income ratio on the profitability of banks. Maswana (2010) studied the FDI and banking sector interactions in the context of China and found that FDI inflows can be attracted with the banking development. Ferrouhi (2014) documented the positive influence of bank size and FDI on the profitability of banks. Lartey et al (2013) studied the trends of net interest margin and return on assets and also the relationship between these two variables, return on assets as a dependent variable for measuring the profitability of listed banks in Ghana and net interest margin as an independent variable. They found a significant positive correlation between net interest margin and return on assets and also the significant regression coefficient with high explanatory power $\mathrm{R}^{2}$ of $82.6 \%$.

Ong and Teh (2013) examined the negative impact of non-performing loans on the bank profitability that further enhance the loan loss provision. Alper and Anbar (2011) observed a positive influence of asset size and non interest income on profitability of banks whereas negative influence of loans under follow up and credit portfolio size on banks' profitability has been noticed. Said and Tumin (2011) investigate empirically and observed a negative relation between operating expenses and profitability of banks. Nwezi (2009) opined a positive relationship of bank size and its profitability level as large bank size helps in attaining economies of scale, reduction in cost and increase in synergy. Bennaceur and Goaied (2008) examined the influence of macroeconomic factors and bank size upon the profitability level of banks. The findings of study exhibit a negative impact of bank size and positive influence of overhead expenses and capital upon the profitability level of banks. The results suggest that macroeconomic variables have no significant influence on the profitability of banks in Tunisia. Kosmidou (2008) analyze the performance determinants of commercial banks of Greek during his study for time period from 1990 to 2002. The findings of the study suggest positive relationship between capitalizations, cost to income ratio and GDP with bank profitability whereas negative impact of inflation has been noticed on the profitability of banks.

Sufian and Chong (2008) reported a negative influence of bank size, credit risk and inflation on profitability whereas capitalization gave the reverse impact on profitability of banks. Athanasoglou et al (2006) argued with its contradictory finding that beyond a certain limit the positive relation turns into negative between bank size and profitability of banks. AL Omar and AL Mutairi (2008) studied return on assets as one of the indicators of the banks' profitability in the context of Kuwait. In their study, credit-deposit ratio and cash-deposit ratio has been used as a measure of lending capacity and liquidity positions of the commercial banks, respectively. Stiroh and Rumbie (2006) observed in their study that bank profitability does not increase with increase in diversification of operations of banks. So, noninterest income activities must be standardised at some level. Staikouras and Wood (2004) identified a negative impact of increase in loan volume with lower margin on the profitability 


\section{Macrothink}

International Journal of Accounting and Financial Reporting

ISSN 2162-3082

2017, Vol. 7, No. 2

of banks. Cooper et al (2003) examined the impact of credit risk on profitability of banks in their study. The empirical results of the study shows a negative impact of increase in credit risk on the heath of banks as well as on their profitability. Abreu and Mendes (2002) examined the determinants of profitability in European banks and found that lower bankruptcy cost enhances their profitability.

\section{Empirical Test Design}

\subsection{Data Set and Sample Design}

The prime data source for financial information of Indian Public sector banks is CAPITALINE database from where we obtained annual financial data of 28 Indian Public Sector banks for the analysis. Our research sample comprises balanced panel dataset of 280 observations over a period from 2006-07 to 2015-16. The rationale behind selecting the public sector banks is the total market share cover by them. The public sector banks enjoy the big slice of customer base in Indian banking sector. The rationale behind selecting the time period from 2006-07 to 2015-16 was to cover the beginning of financial crisis period as banks and financial institutions have been encountered many financial challenges across the globe during financial meltdown. Any active bank which is operated under the supervision of central government of India was selected for research sample. It is imperative for the banks to meet the following condition to be included in the current research study sample. First it should have consistent and accessible financial data from 2006-07 to 2015-16.

\subsection{Dependent and Independent Measures}

In the following section we describe the various research measures (Dependent and Independent) that were selected for the current study on bank profitability. After the completion of literature review in the present study, the following dependent and independent variables have been identified representing the profitability of banks and the bank-specific determinants deriving this profitability, respectively. In the above discussed literature in section 3, the scholars used different ratios for measuring bank profitability (Sharifi and Akhter , 2016; Ong and Teh, 2013; Ihnatov, 2015). The current research makes an attempt to cover the liquidity dimension of bank profitability. The current study postulates Net profit to Total Funds as dependent variable as it covers the inflation variance that makes it more effective. The scholars in the past used conventional profitability measures that are inflation invariant. Net Profit to Total funds is used as the proxy for bank profitability. It indicates the net profit that bank earned from its total funds employed. It measures the efficiency of bank to generate profit from every single rupees of stakeholders' investment. Seven bank specific independent measures are considered as potential determinants of bank profitability. The ratio of Profit before provisions over Total funds is incorporated as independent variable in current study. This ratio intends to measure the management efficiency of banks. It indicates the efficiency of banks to generate profit (before it kept aside for provisions) from their funds employed. Deposits are considered as the main revenue earning tool for banking sector and are expected to have probable effect on bank profitability. Investment to Deposit ratio, Credit to deposit ratio and cash to deposit ratio are considered as another significant independent measures in bank profitability. Investment to Deposit ratio indicates the percentage amount of 
deposits used by banks for further investments like buying of government bonds. Higher investment deposit ratio shows the high dependability of banks for investment on the deposits. Credit to Deposit ratio indicates the percentage of loan assets created by the banks from its deposits. This ratio indicates the utilisation of core funds by the banks for lending purpose. Cox (1966) described Credit to Deposit ratio as crude index of measuring liquidity positions of the commercial banks. Atemnkeng and Joseph, 2006; Goel and Kumar, 2016; found that loan-deposit ratio has a significant positive impact on the banks' profitability. The third deposit measure for bank profitability considered under current study is Cash to Deposit ratio. The report of Reserve Bank of India ${ }^{4}$ described Cash to Deposit ratio as the utilisation of core funds of banks for lending purpose. Other Income to Total Income ratio is also expected to be significant independent measure of bank profitability. Damankah et al (2014) analysed the non-interest income of commercial banks in Ghana. The focus of commercial banks have recently been shifted from interest generating activities to fee-based generating activities due to increased competition among banks and businesses, communication and technology environment, demand of financial services by the business firms. They found that the smaller banks are more focused than the large banks in generating revenues from non-interest income activities. Interest earning on the credit is the main source of income for the banks. Interest Expended to Interest Earned ratio indicates the amount spend on paying the interest as liabilities by the banks as a percentage of amount earned as an interest income by the banks. Higher the ratio lower is the profitability of company as interest expenses are higher than interest income. The financial ratio Interest Income to Total funds measures the amount of interest income earned with the use of total funds of the bank. Interest income is considered as the main source of income for banks. High level of this financial ratio is expected to have a positive influence on the profitability of banks.

\subsection{Empirical Test Approach}

To analyze the pooled balanced times series cross sectional data, panel techniques has been applied as it allows to measure the individual variability and dynamic changes among cross-section units over time (Green, 2004). The pooled least square regression method was employed through statistical software STATA. The ordinary least square regression (OLS) was used by majority of scholarly studies in the past on bank profitability (Garcia Herrero, 2009; Athanasoglou et al., 2005). The OLS regression minimizes the variance and biasness in the data (Koutsoyiannis, 2003). Panel data analysis is employed to analyze the effect of independent variables on the profitability of banks. Panel data is effective in eliminating endogeneity among research variables. The existence of endogeneity among independent variables may lead to biased coefficient estimates (Gujrati, 2014). The multi-collinearity among independent variables is analyzed by applying Variance Inflation Factor (VIF) test. The VIF value lesser than 10 indicates the non- existence of multi-collinearity among independent variables and vice versa. Hausman test is used to select the suitable regression model out of Fixed Effect Model and Random Effect Model that can be applied for analyzing the data (Baltagi, 2001). $\mathrm{P}>\mathrm{Z}$ value was used to decide whether the regression coefficient of a particular independent variable is significant in its relationship with the dependent variable. The variables for which the value of $\mathrm{P}>\mathrm{Z}$ is less than 0.05 show the significant impact on the 


\section{MlMacrothink}

International Journal of Accounting and Financial Reporting

ISSN 2162-3082

2017, Vol. 7, No. 2

dependent variable whereas the variables which have the value more than 0.05 show no significant impact on the dependent variable.

To analyze the probable effect of bank specific independent variables (seven financial ratios) on the bank profitability in Indian public sector banks the following regression model is applied.

$$
\mathrm{Y}_{\mathrm{it}}=\alpha+\sum_{j=1}^{n} \mathrm{X}_{\mathrm{j}} \mathrm{Z}_{\mathrm{ji}}+\epsilon_{\mathrm{i}}
$$

Where,

$\mathrm{Y}_{\mathrm{jt}}=$ profitability of bank $\mathrm{j}$ at time $\mathrm{t}$

$\mathrm{X}_{\mathrm{j}}=$ regression coefficient of bank $\mathrm{j}$

$\mathrm{Z}_{\mathrm{ji}}=$ bank specific Independent variables (financial ratio) of bank $\mathrm{j}$ at time $\mathrm{t}$

$\epsilon_{\mathrm{i}}=$ error term (normal distributed random variable term)

\section{Findings and Discussion}

This section investigates the empirical approach employed to test the research hypotheses and discuss the econometric results of statistical tests including Multi collinearity test, Hausman test and regression analysis.

Table 1. Multi - Collinearity Test

\begin{tabular}{cll}
\hline S. No. & \multicolumn{1}{c}{ Variable Name } & VIF \\
\hline 1. & $\frac{\text { Other Income }}{\text { Total Income }}(\mathrm{OI} / \mathrm{TI})$ & 2.88 \\
\hline 2. & $\frac{\text { Profit Before Provisions }}{\text { Total Funds }}(\mathrm{PBP} / \mathrm{TF})$ & 3.67 \\
\hline 3. & $\frac{\text { Interest Expended }}{\text { Interest Earned }}(\mathrm{IE} / \mathrm{IEarn})$ & 3.08 \\
\hline 4. & $\frac{\text { Credit }}{\text { Deposit }}$ (C/D) & 1.45 \\
\hline 5. & $\frac{\text { Investment }}{\text { Deposit }}$ (I/D) & 1.52 \\
\hline 6. & $\frac{\text { Cash }}{\text { Deposit }}(\mathrm{C} / \mathrm{D})$ & 1.45 \\
\hline 7. & $\frac{\text { Interest Income }}{\text { Total Funds }}(\mathrm{II} / \mathrm{TF})$ & 1.99 \\
\hline
\end{tabular}

Source: VIF Test Output 


\section{MIMacrothink}

International Journal of Accounting and Financial Reporting

ISSN 2162-3082

2017, Vol. 7, No. 2

The Table 1 depicts the statistical value of Variance Inflation Factors (VIF) for analyzing the Multi collinearity in the selected research data. VIF values of all the above variables fall under 10 that gives sufficient evidence of the non existence of multi collinearity among independent variables. It supports the fact that the given research data is unbiased and is relevant to produce reliable output.

\subsection{Hausman Test}

Hausman test has been performed to select the appropriate regression model between Fixed Effect and Random Effect for execution of Panel Data Analysis.

Table 2. Hausman Test

\begin{tabular}{cc}
\hline Test Statistics & Values \\
\hline $\mathrm{Chi}^{2}$ & 32.61 \\
\hline$P>\mathrm{Chi}^{2}$ & 0.000 \\
\hline
\end{tabular}

Source: Hausman Test Output in STATA

Table 2 reports the statistical output executed for Hausman test. The results reveal that the value of Prob $>$ chi2 is less than 0.05 (Prob $>$ chi $2=0.0000$ ). It indicates that fixed effect regression model must be preferred over random effect model (Damodar et al. 2012).

Table 3. Regression Statistics

\begin{tabular}{cccc}
\hline S. No. & Variables & Co-efficient & Significance level \\
\hline 1 & $\frac{\text { Other Income }}{\text { Total Income }}(\mathrm{OI} / \mathrm{TI})$ & $-0.0204^{* *}$ & 0.043 \\
\hline 2 & $\frac{\text { Profit Before Provisions }}{\text { Total Funds }}(\mathrm{PBP} / \mathrm{TF})$ & $0.8237^{*}$ & 0.000 \\
\hline 3 & $\frac{\text { Interest Expended }}{\text { Interest Earned }}(\mathrm{IE} / \mathrm{IEarn})$ & 0.0013 & 0.820 \\
\hline 4 & $\frac{\text { Credit }}{\text { Deposit }}(\mathrm{Cr} / \mathrm{D})$ & $0.0022^{* *}$ & 0.025 \\
\hline 5 & $\frac{\text { Investment }}{\text { Deposit }}(\mathrm{I} / \mathrm{D})$ & 0.0017 & 0.682 \\
\hline 6 & $\frac{\text { Cash }}{\text { Deposit }}(\mathrm{Ca} / \mathrm{D})$ & $0.0586^{*}$ & 0.000 \\
\hline 7 & $\frac{\text { Interest Income }}{\text { Total Funds }}(\mathrm{II} / \mathrm{TF})$ & $-0.0920^{* *}$ & 0.015 \\
\hline 8 & Constant & -0.5053 & 0.282 \\
\hline
\end{tabular}




\begin{tabular}{ccc}
\hline R-Square & 0.5303 & \\
\hline Adjusted R-Square & 0.5182 & \\
\hline Prob > F & $43.86^{*}$ & 0.000 \\
\hline
\end{tabular}

Source: Regression Output in STATA

$* *$ and $*$ indicate the significance level at $5 \%$ and $1 \%$, respectively.

Table 3 shows the p-value for the independent variables under current study and other regression statistics. The R-square results indicate how bank specific independent variables are related to the dependent variable (bank profitability). The adjusted R-squared statistics documents the rigorousness of additional independent variables with statistical shrinkage. The low difference between $\mathrm{R}$ - square and Adjusted R- square confirms the acceptance level of correlation between bank profitability variable and independent variables. The high value of R-square (0.5303) and Adjusted R - square (0.5182) ensure the high explanatory power of the model. The results document sufficient evidence that $53 \%$ of the variation in dependent variable is caused by the bank specific independent variables in the current study.

The results documented in the third column under the nomenclature of co-efficient indicate the effect of independent variables on the dependent variable. The variable other income to total income and Interest income to Total funds exhibit negative coefficient that shows their negative influence on the bank profitability. The positive coefficient of other variables indicates their positive effect on the bank profitability. The $p$ value statistics in the depicted in column four of above table indicates that all the independent variables (OI/TI, PBP/TF, Cr/D, $\mathrm{II} / \mathrm{TF}$ and $\mathrm{Ca} / \mathrm{D}$ ) except (I/D and IE/IEarn) have significant value lower than level of significance 0.05. It gives evidence that the independent variables (OI/TI, PBP/TF, Cr/D, $\mathrm{II} / \mathrm{TF}$ and $\mathrm{Ca} / \mathrm{D}$ ) have significant effect on the profitability of banks whereas I/D and IE/IEarn have no significant effect on the profitability of banks in case of public sector banks in India.

\subsection{Regression Equation}

The following regression equation has been generated on the basis of statistics depicted in Table 3. The regression equation indicates the relationship between dependent variable and independent variables. The regression equation is given below:

$$
\begin{aligned}
\frac{\text { Net Profit }}{\text { Total Funds }}= & -0.5053-0.0204\left(\frac{\text { Other Income }}{\text { Total Income }}\right)+0.8237\left(\frac{\text { Profit Before Provisions }}{\text { Total Funds }}\right) \\
& +0.0013\left(\frac{\text { Interest Expended }}{\text { Interest Earned }}\right)+0.0022\left(\frac{\text { Credit }}{\text { Deposit }}\right)+0.0017\left(\frac{\text { Investment }}{\text { Deposit }}\right) \\
& +0.0586\left(\frac{\text { Cash }}{\text { Deposit }}\right)-0.0920\left(\frac{\text { Interest Income }}{\text { Total Funds }}\right)
\end{aligned}
$$




\section{Mll Macrothink}

International Journal of Accounting and Financial Reporting

ISSN 2162-3082

2017, Vol. 7, No. 2

On the basis of above regression equation, it can be noticed that two independent (Other Income / Total Income) and (Interest Income / Total Funds) are negative correlated with Dependent Variable (Net Profit / Total Funds) whereas other variables have positive correlation with the dependent variable.

\section{Conclusion}

The present study makes an attempt to assess the impact of bank-specific determinants which could lead to the profitability of public sector banks in India. A pooled annual data for 28 public sector banks covering the period from 2006-07 to 2015-16 is used to estimate a nine years variables regression model. The effect of all the independent variables The results indicate that non-interest to total income ratio, profit before provisions to total funds ratio, interest expanded to interest earned ratio, credit- deposit ratio, investment-deposit ratio, cash-deposit ratio, interest income to total funds ratio, explain about $53 \%$ of the variation in ROCE. The impact of these bank-specific determinants of profitability of banks is consistent with theory, . The results give stress on improving credit-deposit and cash-deposit ratios as higher value of these ratios leads to enhance the liquidity risk in financial institutions and will negatively hit the performance of banks. The present study confirms the importance of these five bank-specific determinants in explaining the behaviour of bank profitability in the case of Indian public sector banks.

In the current volatile business environment, financial institutions left no stone unturned to give boost to their profitability. The present research aims at assessing the impact of financial variables on bank profitability for 280 observations over a period of ten years from 2006-07 to 2015-16. After analyzing the research data under study we can conclude that empirical findings are somewhat consistent with existing literature. The banks should focus on reducing the liquidity risk that will shed a positive impact on their performance and profitability. Fund management efficiency including investment and expenditure decision should be given a specific attention by the financial institutions.

\section{Implications and Future Research}

This empirical investigation provides important insight to the banks for focusing on the internal factors which drive the profitability. As recommendations to policy makers, banks and financial institutions should give more focus on improving the efficiency of fund management. This can be attained by diversification of funds in investment venture that follow North West direction under Markowitz postulate (Higher return at minimum risk level). The empirical results of present research study will prove very handful for financial analysts and its statistical findings must embark new dimensions in profitability.

On the basis of the experience and knowledge gained during the current study, some valuable suggestions have been made as possible directions to the future research. The future research can expand the horizon by introducing additional variables like taxation, regulation indicators and quality indicators services offered by banks. The scholars can also extend the research by analyzing the differences in profitability determinants between large and small banks or 
public and private banks. The inclusion of merger and acquisition effect and effect of human capital capability on bank's profitability may also provide cutting edge to the future research.

\section{References}

Abreu, M., \& Mendes, V. (2002). Commercial bank interest margins and profitability: evidence from E.U. Countries. University of Porto Working paper Series, 122.

AL Omar, H., \& AL Mutairi, A. (2008). Bank Specific Determinants of Profitability: The case of Kuwait, Journal of Economic and Administrative Sciences, 24(2), 20-34.

Alalaya, M., \& Al Khattab, S.A. (2015). A Case Study in Business Market: Bank's Profitability: Evidence from Jordanian Commercial Banks. International Journal of Business Management and Economic Research, 6(4), 204-213.

Altunbas, Y., Gardener, E.P.M., Molyneux, P., \& Moore, B. (2001), Efficiency in European Banking. European Economic Review, 45(10), 1931-1955

Atemnkeng, T., \& Joseph, N. (2006). Market structure and profitability performance in the banking industry of CFA Countries: the case of commercial banks in Cameroon. Retrieved 13 August 2017, from http://www.jsdafrica.com/Jsda/Summer_2006/PDF/ARC_MarketStructureProfitabilityPerfor mace.pdf

Athanasoglou, P.P., Brissimis S.N., \& Delis. (2008). Bank Specific, Industry Specific and Macroeconomic Determinants of Bank Profitability. Journal of International Financial Markets, Institutions and Money, 18(2), 121-36.

Baltagi, B.H. (2001). Econometric Analysis of Panel Data. John Wiley \& Sons, Chichester.

Bennaceur, S., \& M. Goaied. (2008). The Determinants of Commercial Bank Interest Margin and Profitability: Evidence from Tunisia. Frontiers in Finance and Economics, 5(1), 106-130.

Capraru, B., \& Ihnatov, I. (2015). Determinants of bank's profitability in EU15, Scientific Annals of the "AlexandruIoanCuza", 62(1), 93-101.

Cooper, M., W. Jackson, \& G. Patterson. (2003). Evidence of Predictability in the Cross Section of Bank Stock Returns, Journal of Banking and Finance, 27(5), 817-50.

Cox, J. W. (1966). Developments in the Commercial Bank Loan-Deposit Ratio. Monthly Review (March), Federal Reserve Bank of New York, 65-70.

Damanakh, B. S., Anku-Tsede, O., \& Amankwaa, A. (2014). Analysis of Non-Interest Income of Commercial Banks in Ghana. International Journal of Academic Research in Accounting, Finance and Management Sciences, 4(4), 263-271.

Damodar, Gujarati N., Dawn C. Porter, \& Gunasekar, Sangeeta. (2008), Panel Data Regression. Basic Econometrics. New York: Mc-Graw Hill, pp. 637-639.

Elisa Menicucci, \& Guido Paolucci. (2016). The determinants of bank profitability: empirical evidence from European banking sector. Journal of Financial Reporting and Accounting, 14(1), 86-115.

Ferrouhi, E. (2014). Bank Liquidity and Financial Performance: Evidence from Moroccan Banking Industry. Business: Theory \& Practice, 15(4), 351-361. 


\section{Macrothink}

International Journal of Accounting and Financial Reporting ISSN 2162-3082

Goel, S., \& Kumar, R. (2016). Analysis of Cash - Deposit Ratio \& Credit-Deposit Ratio of Public Sector Banks in India. International Journal of Research in Management, Science \& Technology, 4(2), 72-74.

Govil, M., \& Tripathi, M. (2014). Financial Performance of Top Ranking Indian Banks in the Post Crisis Period. Prestige e-Journal of Management and Research, 1(1).

Greene, W.H. (2004). Fixed Effects and Bias Due tothe Incidental Parameters Problem in the Tobit Model. Eonometric Reviews, 23(2), 125-147.

Haque, M. I., \& Sharman, R. B. (2011). Benchmarking Financial Performance of Saudi Banks Using Regression. International Journal of Business Economics and Management Research, 2(1), 78-84.

Kosmidou, K. (2008). The Determinants of Banks' Profits in Greece during the Period of EU Financial Integration. Managerial Finance, 34(3), 146-59.

Koutsoyiannis, A. (2003). Theory of Econometrics (2nd ed.). Macmillan Publishers Ltd, London.

Lartey, V. C., Antwi, S., \& Boadi, E. K. (2013). The Relationship between Net Interest Margin and Return on Assets of Listed Banks in Ghana. Research Journal of Finance and Accounting, 4(16), 73-78.

Maswana, J.C. (2010). An empirical investigation into the banking intermediation and Foreign Direct Investment inflows in China. International Journal of Business and Emerging Markets, 2(2), 193 - 209.

Mohan, R., \& Ray, P. (2017). Indian Financial Sector: Structure, Trends and Turns. IMF Working Paper, WP/17/7.

Nzewi, U.C. (2009). An Analysis of the profitability of commercial banks in the post consolidation period in Nigeria. Journal of the Management Sciences, 9(2), 179-196.

OngTze, S., \& TehBoon, H. (2013). Factors affecting the profitability of Malaysian Commercial Banks. African Journal of Business Management, 7(8), 649-660.

Pant, A., \& Nidugala, G.K. (2017). Macro Determinants of CAR in Indian Banking Sector. The Journal of Developing Areas, 51(2), 59-70.

Rena, R. (2009). Indian economy: financial sector reforms and development. International Journal of Business and Emerging Markets, 1(4), 387-404.

Said, R. M., \& Tumin, M.H. (2011). Performance and Financial Ratios of Commercial Banks in Malaysia and China. International Review of Business Research Papers, 7(2), 157-169.

Samad, A. (2015). Determinants Bank Profitability: Empirical Evidence from Bangladesh Commercial Banks. International Journal of Financial Research, 6(3), 173-179.

Sharifi, O., \& Akhter, J. (2016). Performance of Banking through Credit-Deposit Ratio in Public Sector Banks in India. International Journal of Research in Management \& Technology, 6(4), 14-18.

Singh, C. (2016). An Essay on Banking and Macroeconomics: Role of Public Sector Banks in India. IIMB-WP N0. 530.

Staikouras. C., \& Wood, G. E. (2004). The Determinants of European bank Profitability. International Business \& Economics Research Journal, 3(6), 57-68. 


\section{MInstitute ${ }^{\text {Mink }}$}

International Journal of Accounting and Financial Reporting ISSN 2162-3082

Stiroh, K., \& Rumbie, A. (2006). The dark side of diversification: The case of US financial holding companies. Journal of Banking and Finance, 30, 2131-2161.

Sufian. F., \& Chong. R. (2008). Determinants of bank profitability in a developing economy: empirical evidence from the Philippines. Asian Academy of Management Journal of Accounting and Finance, 4(2), 91-112.

\section{Notes}

Note 1. https://www.ibef.org/industry/banking-india.aspx, accessed 12 November 2017

Note 2. https://www.imf.org/ /media/Files/Publications/WP/wp1707.ashx, accessed 14 November

2017

Note

https://rbidocs.rbi.org.in/rdocs/Publications/PDFs/0FRTP16A120A29D260148E58B484D4A 60E381BB.PDF, accessed 15 November 2017

Note 4. Statistical Tables Relating to Banks in India, 2015, https://rbidocs.rbi.org.in/rdocs/PressRelease/PDFs/PR1493D789DCB7F46A4D608B2C82F4 E1360C82.PDF, accessed 17 October 2017

\section{Copyright Disclaimer}

Copyright for this article is retained by the author(s), with first publication rights granted to the journal.

This is an open-access article distributed under the terms and conditions of the Creative Commons Attribution license (http://creativecommons.org/licenses/by/4.0/) 